\title{
Perceived Social Support of the Adolescents from Rural and Urban Setting
}

\author{
Richa Nautiyal $^{1 *}$, Prof. A. Velayudhan ${ }^{2}$, Dr. S. Gayatridevi ${ }^{3}$
}

\section{ABSTRACT}

Adolescence (from Latin adolescere, meaning "to grow up") is a transitional stage of physical and psychological human development that generally occurs during the period from puberty to legal adulthood (age of majority). Social support is defined as the belief that others understand your needs and will try to help you. Social support is any type of communication that helps the individual feel more certain about the situation and therefore feel as if they have a control over it. The present study examines the perceived social support of the adolescents in an urban and a rural setting. Multidimensional Scale of Perceived Social Support (MSPSS) developed by Zimet, Dahlam, Zimet and Farley (1988) was used in the present study. Based on the statistical analysis the results are discussed and conclusions are arrived at.

Keywords: Perceived Social Support, Adolescence, Kerala

Adolescence (from Latin adolescere, meaning "to grow up") is defined as a transitional stage of physical and psychological human development that generally occurs during the period from puberty to legal adulthood (age of majority). The formal study of adolescent psychology began with the publication of G. Stanley Hall's "Adolescence in 1904." Hall, who was the first president of the American Psychological Association, viewed adolescence primarily as a period of "Sturm und Drang - storm and stress." He defined this period to begin at puberty at about 12 or 13 years, and end late, between 22 years to 25 years of age.

Freud believed that adolescence was a universal phenomenon and included behavioral, social and emotional changes; not to mention the relationships between the physiological and psychological changes, and the influences on the self-image. He also stated that the physiological changes are related to emotional changes, especially an increase in negative emotions, such as

\footnotetext{
${ }^{1}$ Doctoral Scholar, Department of Psychology, Bharathiar University, Coimbatore, India

${ }^{2}$ Department of Psychology, Bharathiar University, Coimbatore, India

${ }^{3}$ Associate Professor (SG), Avinashilingam University for Women, Coimbatore, India *Responding Author
}

Received: January 23, 2017; Revision Received: February 12, 2017; Accepted: February 15, 2017 (C) 2017 Nautiyal R, Velayudhan A, Gayatridevi S; licensee IJIP. This is an Open Access Research distributed under the terms of the Creative Commons Attribution License (www.creativecommons.org/licenses/by/2.0), which permits unrestricted use, distribution, and reproduction in any Medium, provided the original work is properly cited. 


\section{Perceived Social Support of the Adolescents from Rural and Urban Setting}

moodiness, anxiety, loathing, tension and other forms of adolescent behavior. Whereas Erikson described adolescence as the period during which the individual must establish a sense of personal identity and avoid the dangers of role diffusion and identity confusion (Erikson, 1950). Social support is a broad term encompassing a variety of more specific characteristics of an individual's social world that might promote well-being and/or increase resistance to health problems (Cohen, Gottlieb, \& Underwood, 2000). Social support processes are strongly linked to mental and physical health (House, Landis, \& Umberson, 1988).

In a qualitative study of adult individuals with developmental disabilities, King et al. (2006) found that social support played a significant role in reducing life strains facing individuals with disabilities. The participants experienced receiving emotional, instrumental, and cognitive (e.g., affirmation, confirmation, and coherence in self-concept) support, which fostered resiliency in them.

Luszczynska, Sarkar, and Knoll (2007) found in a sample of 104 HIV-positive heterosexual men and women that both social support and self-efficacy were related to better physical functioning among them. Knoll and Schwarzer (2002) illustrated that women who reported the highest social support had the lowest levels of negative affect and depression, and reported the fewest health complaints, whereas the social support levels of men were not linked to their depression and health complaints.

In an effort to better understand more specific social support mechanisms, scholars have described social support as a "meta-construct" consisting of several sub-constructs (Heller \& Swindle, 1983; Vaux, Riedel, \& Stewart, 1987). Two of these sub constructs are received social support and perceived social support. Measures of received social support are designed to assess the specific supportive behaviors that are provided to recipients by their support networks. Perceived social support measures assess recipients' perceptions concerning the general availability of support and/or global satisfaction with support provided (Sarason, Sarason, \& Pierce, 1990).

Researches indicate that in general, perceived social support is associated with improved physical and mental health (House, Umberson, \& Landis, 1988; Lakey \& Cronin, 2008; Uchino, 2009), and that perceived support is more essential than received support in predicting adjustment to life stress (Wethington \& Kessler, 1986).

A study conducted with thirty orphaned children in Trichy, Tamil Nadu found that there is more perceived social support rendered by significant others when they were not aware of the parents HIV status. They also found out that the children from scheduled caste experience less social support from the family when compared to the children from the other castes. (Elamurugu \& Indiramma, 2015). Another study that was conducted with an aim to study the effect of social 


\section{Perceived Social Support of the Adolescents from Rural and Urban Setting}

networking sites and perceived social support on the psychological well-being of the youth found out that a positive relationship existed between online perceived social support and psychological wellbeing. (Misra, Dangi \& Patel, 2015).

The adolescents today, may they be from a rural or an urban background has a lot to work on and they need all the assistance they can get. But for that to happen one must know where each of them lack support and what can be done to help them evolve and lead a more wholesome life. The present study intends to examine if there is a difference in perceived social support among adolescents in an urban and rural setting. This studies aims to bridge in the gap between the way adolescents perceive social support which could help them lead a more satisfactory life.

\section{Hypothesis}

1. There is significant difference between the perceived social support among adolescent in an urban and rural setting.

2. There is significant difference between the perceived social support among adolescent boys and girls.

\section{METHODOLOGY}

\section{Participants}

The data for the study was collected from adolescents using purposive sampling. 100 adolescents were selected for the study out of which 50 (25- boys, 25- girls) were from an urban region and the other 50 (25-boys, 25-girls) were from a rural region.

\section{Materials}

Multidimensional Scale of Perceived Social Support (MSPSS): Social support was assessed through Multidimensional Scale of Perceived Social Support (MSPSS) developed by Zimet, Dahlam, Zimet and Farley (1988). This is a 12 item measure of subjectively assessed social support. It measures social support from three sources: (a) Family, (b) Friends and (c) Significant Others. Responses are rated on a 7-point Likert-type response format (1- very strongly disagree; 7- very strongly agree) and range between low point of strongly disagree to a high point of strongly agree. The score are summed up to get the total score on the three dimensions.

\section{Statistical analysis}

Mean, Standard deviation and t- test was used to assess the difference in the perceived social support among adolescents in an urban and rural setting. 


\section{RESULTS}

Table 1 - Descriptive statistics and t test results of perceived social support of adolescence residing in an urban and rural setting

\begin{tabular}{|c|c|c|c|c|c|c|c|}
\hline & Locations & $\mathbf{N}$ & Mean & Std. Deviation & $\mathbf{t}$ & df & Sig. (2-tailed) \\
\hline \multirow{2}{*}{ Family } & $\mathrm{U}$ & 50 & 12.44 & 3.233 & \multirow{2}{*}{-10.578} & \multirow{2}{*}{98} & \multirow{2}{*}{ * } \\
\hline & $\mathrm{R}$ & 50 & 19.28 & 3.233 & & & \\
\hline \multirow{2}{*}{ Friends } & $\mathrm{U}$ & 50 & 19.24 & 2.932 & \multirow{2}{*}{-.731} & \multirow{2}{*}{98} & \multirow{2}{*}{ N.S } \\
\hline & $\mathrm{R}$ & 50 & 19.70 & 3.346 & & & \\
\hline \multirow{2}{*}{$\begin{array}{c}\text { Significant } \\
\text { Others }\end{array}$} & $\mathrm{U}$ & 50 & 16.22 & 5.242 & \multirow{2}{*}{1.263} & \multirow{2}{*}{98} & \multirow{2}{*}{ N.S } \\
\hline & $\mathrm{R}$ & 50 & 15.04 & 4.020 & & & \\
\hline \multirow{2}{*}{ Total } & $\mathrm{U}$ & 50 & 47.90 & 6.361 & \multirow{2}{*}{-5.127} & \multirow{2}{*}{98} & \multirow{2}{*}{ * } \\
\hline & $\mathrm{R}$ & 50 & 54.02 & 5.549 & & & \\
\hline
\end{tabular}

The data indicates that the adolescents from urban feel that the social support that they receive from their family is less as compared to their rural counterparts. However there is no significant difference in the way adolescent's judge support from their friends or significant others. The data also illustrates that there is a significance difference in the way adolescents perceive social support with rural teenagers having a more positive social support then the urban teenagers.

Table 2 - Descriptive statistics and t test results of perceived social support among adolescent boys and girls

\begin{tabular}{|c|c|c|c|c|c|c|c|}
\hline & Gender & $\mathbf{N}$ & Mean & Std. Deviation & $\mathbf{t}$ & df & Sig. (2-tailed) \\
\hline \multirow{2}{*}{ Family } & $\mathrm{F}$ & 50 & 16.22 & 4.377 & \multirow{2}{*}{.763} & \multirow{2}{*}{98} & \multirow{2}{*}{ N.S } \\
\hline & $\mathrm{M}$ & 50 & 15.50 & 5.036 & & & \\
\hline \multirow{2}{*}{ Friends } & $\mathrm{F}$ & 50 & 18.12 & 2.592 & \multirow{2}{*}{-4.747} & \multirow{2}{*}{98} & \multirow{2}{*}{$*$} \\
\hline & M & 50 & 20.82 & 3.075 & & & \\
\hline \multirow{2}{*}{$\begin{array}{c}\text { Significant } \\
\text { others }\end{array}$} & $\mathrm{F}$ & 50 & 17.72 & 4.664 & \multirow{2}{*}{4.965} & \multirow{2}{*}{98} & \multirow{2}{*}{$*$} \\
\hline & $\mathrm{M}$ & 50 & 13.54 & 3.699 & & & \\
\hline \multirow{2}{*}{ Total } & $\mathrm{F}$ & 50 & 52.06 & 6.195 & \multirow{2}{*}{1.659} & \multirow{2}{*}{98} & \multirow{2}{*}{ N.S } \\
\hline & M & 50 & 49.86 & 7.036 & & & \\
\hline
\end{tabular}

* - Significant at 0.05 level N.S - Not significant

The data obtained indicates that adolescent boys feel they get more social support from their friends than their female counterparts. However the females feel their significant others provide more support to them than what the boys get from their significant others.

(c) The International Journal of Indian Psychology, ISSN 2348-5396 (e)| ISSN: 2349-3429 (p) | 189 


\section{CONCLUSIONS}

Man is a social animal and cannot survive in this world alone. Researches over the years have highlighted the importance of social support in the life of an individual. Social support has a very positive effect on a person's psychological wellbeing and therefore must be encouraged.

One of the reasons for a low score among urban adolescents may be due to the hectic lifestyle of the kids as well as the parents. It may also be because nowadays people have a nuclear family structure unlike before where people used to stay in joint families. The overall results indicated that the adolescents living in rural settings have scored higher in perceived social support. This could be due to a stronger sense of community and familiarity prevailing in small villages. Another reason may be that even today, people in rural India still live in joint families and that could lead to a stronger sense of belonging among the teenagers.

The data also indicated that boys when compared to girls scored more in the friend's dimension of perceived social support. This maybe because boys have more independence and can spend more time with each other. Girls on the other hand may not be able to do so because of the various restrictions placed on them. Girls in rural as well as urban areas are still discouraged to mingle with the opposite sex or to have many friends in general. A girl who is an extrovert and has many friends is still judged and frowned upon even in this age and era.

According to the analyzed data adolescent girls get more support from their significant others, this could be due to the fact that girls form more meaningful relationship with people and get more emotionally attached. This leads to a better sense of bonding which in turn is relayed during the time of crisis.

\section{Acknowledgments}

The author appreciates all those who participated in the study and helped to facilitate the research process.

Conflict of Interests: The author declared no conflict of interests.

\section{REFERENCES}

Cohen, S., Gottlieb, B., \& Underwood, L. (2000). Social relationships and health. In S. Cohen, L. Underwood, \& B. Gottlieb (Eds.) Social support measurement and intervention: A guide for health and social scientists. New York: Oxford University Press, 3-25.

Elamurugu, M., \& Indiramma, V. (2015). Perceived Social Support among Children Orphaned by HIV/AIDS in Trichy, India: A Cross-Sectional Study. Journal of School Social Work, 12(2).

Erikson, E.H. (1950). Childhood and society. New York: W.W. Norton.

Freud, S. (1925). Three contributions to the sexual theory. Nervous and Mental Disease Monograph Series, No. 7. New York: Nervous and Mental Disease Publishing Co. 


\section{Perceived Social Support of the Adolescents from Rural and Urban Setting}

Hall, G.S. (1916). Adolescence. 2 vols. New York: Appleton.

Heller, K., \& Swindle, R. W. (1983). Social networks, perceived social support, and coping with stress. In R. D. Felner,L. A. Jason, J. N. Moritsugu, \& S. S. Farber (Eds.), Preventive psychology: Theory, research and practice (pp. 87-103). New York: Pergamon.

House, J. S., Landis, K. R., \& Umberson, D. (1988). Social relationships and health. Science, 241,540-545.

House, J. S., Umberson, D., \& Landis, K. R. (1988). Structures and processes of social support. Annual Review of Sociology, 14,293-318.

King, G., Willoughby, C., Specht, J. A, \& Brown, E. (2006). Social support processes and the adaptation of individuals with chronic disabilities. Qualitative Health Research, 16(7), 902-925.

Knoll, N., \& Schwarzer, R. (2002). Gender and age differences in social support: A study of East German refugees. In G. Weidner, M. S. Kopp, \& M. Kristenson (Eds.), Heart disease: Environment, stress, and gender. NATO cience Series, Series I: Life and Behavioural Sciences, Vol. 327 (pp. 198-210). Amsterdam: IOS Press.

Lakey, B., \& Cronin, A. (2008). Low social support and major depression: Research, theory and methodological issues. In K. S. Dobson \& D. Dozois (Eds.), Risk factors for depression (pp. 385-408). San Diego, CA: Academic Press.

Luszczynska, A., Sarkar, Y., \& Knoll, N. (2007). Received social support, self-efficacy, and finding benefits in disease as predictors of physical functioning and adherence to antiretroviral therapy. Patient Education and Counselling, 66(1), 37-42.

Misra, N., Dangi, S., \& Patel, S. (2015). Gender Differences in Usage of Social Networking Sites and Perceived Online Social Support on Psychological Well Being of Youth.

Muuss, Rolf E. (1975). Theories of Adolescence, 3rd Edition. New York: Random House.

Sarason, B. R., Sarason, I. G., \& Pierce, G. R. (1990). Traditional views of social support and their impact on assessment. In B. R. Sarason, I. G. Sarason, \& G. R. Pierce (Eds.),Social support: An interactional view (pp. 9-25). New York: Wiley.

Uchino, B. N. (2009). Understanding the links between social support and physical health: A lifespan perspective with emphasis on the separability of perceived and received support. Perspectives in Psychological Science, 4,236-255.

Vaux, A., Riedel, S., \& Stewart, D. (1987). Modes of social support: The Social Support Behaviors (SS-B) Scale. American Journal of Community Psychology, 15, 209-237.

Wethington, E., \& Kessler, R. C. (1986). Perceived support, received support, and adjustment to stressful life events. Journal of Health and Social Behavior, 27(1), 78-89.

Zimet, G.D., Dahlem, N.W., Zimet, S.G. \& Farley, G.K. (1988). The Multidimensional Scale of Perceived Social Support. Journal of Personality Assessment, 52, 30-41.

How to cite this article: Nautiyal R, Velayudhan A, Gayatridevi S (2017), Perceived Social Support of the Adolescents from Rural and Urban Setting, International Journal of Indian Psychology, Volume 4, Issue 2, No. 89, ISSN:2348-5396 (e), ISSN:2349-3429 (p), DIP:18.01.098/20170402, ISBN:978-1-365-74162-3 